\title{
Sodium selectivity of Reissner's membrane epithelial cells
}

Muneharu Yamazaki ${ }^{1,2}$, Kyunghee X Kim ${ }^{1}$, Daniel C Marcus $^{1 *}$

\begin{abstract}
Background: Sodium absorption by Reissner's membrane is thought to contribute to the homeostasis of the volume of cochlear endolymph. It was previously shown that the absorptive transepithelial current was blocked by amiloride and benzamil. The most commonly-observed target of these drugs is the epithelial sodium channel (ENaC), which is composed of the three subunits $\alpha-\beta$ - and $\gamma$-ENaC. However, other less-selective cation channels have also been observed to be sensitive to benzamil and amiloride. The aim of this study was to determine whether Reissner's membrane epithelial cells could support parasensory $\mathrm{K}^{+}$absorption via amiloride- and benzamilsensitive electrogenic pathways.

Results: We determined the molecular and functional expression of candidate cation channels with gene array (GEO GSE6196), RT-PCR, and whole-cell patch clamp. Transcript expression analysis of Reissner's membrane detected no amiloride-sensitive acid-sensing ion channels (ASIC1a, ASIC2a, ASIC2b) nor amiloride-sensitive cyclicnucleotide gated channels (CNGA1, CNGA2, CNGA4, CNGB3). By contrast, $\alpha-\beta$ - and $\gamma$-ENaC were all previously reported as present in Reissner's membrane. The selectivity of the benzamil-sensitive cation currents was observed in whole-cell patch clamp recordings under $\mathrm{Cl}^{-}$-free conditions where cations were the only permeant species. The currents were carried by $\mathrm{Na}^{+}$but not $\mathrm{K}^{+}$, and the permeability of $\mathrm{Li}^{+}$was greater than that of $\mathrm{Na}^{+}$in Reissner's membrane. Complete replacement of bath $\mathrm{Na}^{+}$with the inpermeable cation $\mathrm{NMDG}^{+}$led to the same inward current as with benzamil in a $\mathrm{Na}^{+}$bath.

Conclusions: These results are consistent with the amiloride/benzamil-sensitive absorptive flux of Reissner's membrane mediated by a highly $\mathrm{Na}^{+}$-selective channel that has several key characteristics in common with $\alpha \beta \gamma$-ENaC. The amiloride-sensitive pathway therefore absorbs only $\mathrm{Na}^{+}$in this epithelium and does not provide a parasensory $\mathrm{K}^{+}$efflux route from scala media.
\end{abstract}

\section{Background}

The inner ear has absorptive pathways for both $\mathrm{Na}^{+}$and $\mathrm{K}^{+}$that contribute to the homeostasis of the composition of endolymph, the luminal fluid. The regulation of the ion composition of endolymph is essential for normal hearing [1,2]. Transepithelial $\mathrm{K}^{+}$efflux through the sensory hair cells in the cochlea is responsible for detection of sound. Parasensory $\mathrm{K}^{+}$absorption through other cell types is needed to compensate for changes in sensory cell $\mathrm{K}^{+}$flux due to changes in levels of stimulation from acoustic inputs. The cochlear outer sulcus is an

\footnotetext{
* Correspondence: marcus@ksu.edu

'Cellular Biophysics Laboratory, Dept. Anatomy \& Physiology, Kansas State University, Manhattan, KS 66506 USA

Full list of author information is available at the end of the article
}

epithelial domain known to participate in absorption of both $\mathrm{K}^{+}$and $\mathrm{Na}^{+}$[3].

Absorptive mechanisms are needed to remove $\mathrm{Na}^{+}$ from endolymph in order to maintain osmotic balance, to prevent loading of sensory hair cells with $\mathrm{Na}^{+}$and to maintain functional physical properties of the tectorial membrane. $\mathrm{Na}^{+}$, like $\mathrm{K}^{+}$, is absorbed via nonselective cation channels in the apical membranes of outer sulcus cells. In addition, $\mathrm{Na}^{+}$appears to be absorbed via an amiloride-sensitive pathway in Reissner's membrane (RM) of the cochlea.

The transepithelial current across RM was shown to be inhibited by amiloride and its analog, benzamil $[4,5]$. The most commonly-observed target of these drugs is the epithelial sodium channel $(\mathrm{ENaC})$, which is usually composed of the three subunits $\alpha-, \beta$ - and $\gamma$-ENaC.

\section{Ciomed Central}


However, other combinations of $\mathrm{ENaC}$ subunits and other cation channels have also been observed to be sensitive to amiloride and benzamil. Further, those channels are not as selectively permeable to $\mathrm{Na}^{+}$over $\mathrm{K}^{+}$ and would therefore provide a potential pathway for parasensory $\mathrm{K}^{+}$-absorption.

In view of the high luminal concentration of $\mathrm{K}^{+}$in the inner ear (ca. $150 \mathrm{mM}$ ) and the importance of $\mathrm{K}^{+}$efflux pathways for endolymph homeostasis, we investigated whether RM epithelial cells could support parasensory $\mathrm{K}^{+}$ absorption via amiloride-sensitive electrogenic pathways. The results show that acutely isolated RM has a highly $\mathrm{Na}$ ${ }^{+}$-selective transport pathway, without detectable contributions from $\mathrm{K}^{+}$. The processes studied have several properties of the classical $\mathrm{ENaC}$ channel including inhibition by amiloride and benzamil, high selectivity for $\mathrm{Na}^{+}$over $\mathrm{K}^{+}$ and a higher permeability to $\mathrm{Li}^{+}$over $\mathrm{Na}^{+}$.

\section{Results}

We have shown in previous studies that Reissner's membrane in mouse and gerbil absorbs $\mathrm{Na}^{+}$from the cochlear lumen by electrogenic transepithelial transport, which was apparently mediated by apical $\mathrm{ENaC}$, basolateral $\mathrm{Na}^{+}, \mathrm{K}^{+}$-ATPase, and basolateral $\mathrm{K}^{+}$channels $[4,5]$. This $\mathrm{Na}^{+}$absorption was blocked by amiloride and benzamil. The most commonly-observed target of these drugs is $\mathrm{ENaC}$, comprised of the three subunits $\alpha$-, $\beta$ - and $\gamma$-ENaC. We addressed the question of cation selectivity of this pathway in Reissner's membrane epithelial cells with 5 series of patch clamp experiments and selective candidate gene expression analysis.

Benzamil-sensitive currents under whole-cell patch clamp We first tested whether benzamil-sensitive currents, which was earlier observed as transepithelial currents with the current-density vibrating probe [5], could be detected under whole-cell patch clamp conditions (Series 1$)$. Indeed, benzamil $(1 \mu \mathrm{M})$ reduced the inward current when the pipette and bath solutions (P1, B1) approximated the physiological situation (ignoring differences in apical cation and intracellular $\mathrm{Cl}^{-}$composition) (Additional file 1: Fig. S1 and Fig. S3; Table 1).

Indeed, benzamil $(1 \mu \mathrm{M})$ reduced the inward current when the KCl-rich pipette solution (P1) mimicked the presumed intracellular composition (although $\mathrm{Cl}^{-}$was higher than often observed) and when the $\mathrm{NaCl}$-rich bath (B1) mimicked the basolateral (perilymph) composition, (Additional file 1: Fig. S1 and Fig. S3; Table 1). Benzamil was used throughout these experiments at a concentration $(1 \mu \mathrm{M})$ that yielded a complete inhibition of the transepithelial current [5] and significantly inhibited the inward whole-cell current (at $-100 \mathrm{mV} ; \mathrm{I}_{-100}$ ) by 48.5\%; from $-1305 \pm 277 \mathrm{pA}$ to $-671 \pm 146 \mathrm{pA}(\mathrm{n}=7)$. These whole-cell data are consistent with the transepithelial measurements of $\mathrm{Na}^{+}$absorption by Reissner's membrane.

\section{Expression of benzamil-sensitive cation channels in RM}

We utilized gene array and RT-PCR to partially address the question of the participation of benzamil-sensitive nonselective cation (NSC) channels. Several isoforms of acid-sensitive ion channels (ASIC) and cyclic-nucleotide gated (CNG) channels were listed in our gene array of mouse Reissner's membrane (GEO GSE6196; Table 2) [6]. ASIC1a, 2a, 2b, 3 and 4 were listed; ASIC1a and 3 yielded a call of "Present", but ASIC1a was tested by RTPCR and determined to be "Absent" (Table 2). ASIC3 was not determined by RT-PCR; however, ASIC3 is stimulated, rather than inhibited, by amiloride at neutral $\mathrm{pH}$ [7] and therefore would not be expected to contribute to the currents measured in the present study. CNGA1, 2, 4 and CNGB3 were listed in the gene array and all received a call of "Absent". CNGA3 and CNGB1 were not listed in the gene array and were not tested by RTPCR. As mentioned above, ENaC can be a NSC channel under some subunit combinations and the $\alpha-, \beta$ - and $\gamma$ -ENaC subunits were all expressed in RM (Table 2).

\section{$\mathrm{Na}^{+}$and $\mathrm{K}^{+}$conductance of benzamil-sensitive current}

Whole-cell patch clamp currents were measured (Series 2) under conditions where the only major permeant ions were either $\mathrm{Na}^{+}$or $\mathrm{K}^{+}$(Figures 1,2 ). $\mathrm{Cl}^{-}$was replaced by methanesulfonate (Table 3 ). In symmetrical $\mathrm{Na}^{+}$-rich bath and pipette solutions (B2, P2), the current-voltage (I-V) relationship was nearly linear, with a slight inward rectification at large negative voltage. The slight inward rectification observed at large negative voltage in the first series of symmetrical $\mathrm{Na}^{+}$experiments was at least partially due to the time dependence of the response. This series utilized $300 \mathrm{~ms}$ voltage steps and the second linear series utilized $200 \mathrm{~ms}$ steps. The strong rectification of the benzamil-sensitive current, however, may at least partially be due to the known voltage sensitivity of inhibition of $\mathrm{ENaC}$ by benzamil [8-10]. Benzamil significantly inhibited the inward whole-cell current (carried mostly by bath $\mathrm{Na}^{+}$at -100 $\mathrm{mV}$ ) by $87.5 \%$; from $\mathrm{I}_{-100}=-2044 \pm 552 \mathrm{pA}$ to $-255 \pm$ $57 \mathrm{pA}(\mathrm{n}=6)$. Some experiments displayed a slow rundown in channel activity, as has been observed by others $[8,11]$. A representative experiment is shown in Figure 1 and a summary of similar experiments is shown in Figure 2 and Table 1.

In symmetrical $\mathrm{K}^{+}$-rich bath and pipette solutions (B3, $\mathrm{P} 3)$, the current and conductance at $-100 \mathrm{mV}$ were significantly smaller than in $\mathrm{Na}^{+}$(Figures 1, 2; Table 1). Benzamil had no significant effect on the inward wholecell current (carried mostly by bath $\mathrm{K}^{+}$at $-100 \mathrm{mV}$ ) (mean decreased insignificantly by $9.8 \%$; from $\mathrm{I}_{-100}=$ 
Table 1 Inward and outward wholecell patch clamp currents, conductances and reversal voltage under established cationic conditions

\begin{tabular}{|c|c|c|c|c|c|c|c|c|c|c|c|}
\hline \multirow{2}{*}{$\begin{array}{c}\text { Series } 1 \\
\text { Physiological }\end{array}$} & \multirow[b]{2}{*}{ [Pipette]/[Bath] } & \multicolumn{2}{|c|}{$\mathrm{I}(-100)[\mathrm{pA}]$} & \multicolumn{2}{|c|}{$g(-)[n S]$} & \multicolumn{2}{|c|}{$\mathrm{Vr}[\mathrm{mV}]$} & \multicolumn{2}{|c|}{$\mathrm{I}(+100)[\mathrm{pA}]$} & \multicolumn{2}{|c|}{$g(+)[n S]$} \\
\hline & & Benz (-) & Benz (+) & Benz (-) & Benz (+) & Benz (-) & Benz (+) & Benz (-) & Benz (+) & Benz $(-)$ & Benz (+) \\
\hline & $140 \mathrm{KCl} / 150 \mathrm{NaCl}$ & $\begin{array}{c}-1305 \\
\{277(7)\}\end{array}$ & $\begin{array}{c}-671 \neq \\
\{146(7)\}\end{array}$ & $\begin{array}{c}17.2 \\
\{2.1(7)\}\end{array}$ & $\begin{array}{c}10.2 \neq \\
\{1.1(7)\}\end{array}$ & $\begin{array}{c}9.4 \\
\{3.7(7)\}\end{array}$ & $\begin{array}{l}-2.0 \mathrm{~ns} \\
\{5.7(7)\}\end{array}$ & $\begin{array}{c}938 \\
\{367(7)\}\end{array}$ & $\begin{array}{c}708 \mathrm{~ns} \\
\{257(7)\}\end{array}$ & $\begin{array}{c}9.9 \\
\{3.7(7)\}\end{array}$ & $\begin{array}{l}7.2 \mathrm{~ns} \\
\{2.3(7)\}\end{array}$ \\
\hline \multirow[t]{2}{*}{$\begin{array}{l}\text { Series } 2 \\
\text { Na or K Bath }\end{array}$} & $150 \mathrm{Na}-\mathrm{ms} / 150 \mathrm{Na}-\mathrm{ms}$ & $\begin{array}{c}-2044 \\
\{552(6)\}\end{array}$ & $\begin{array}{l}-255 \neq \\
\{57(6)\}\end{array}$ & $\begin{array}{c}25.9 \\
\{7.0(6)\}\end{array}$ & $\begin{array}{c}2.6 \neq \\
\{0.5(6)\}\end{array}$ & $\begin{array}{c}0.5 \\
\{0.5(6)\}\end{array}$ & $\begin{array}{l}-0.9 \mathrm{~ns} \\
\{1.0(6)\}\end{array}$ & $\begin{array}{c}1496 \\
\{363(6)\}\end{array}$ & $\begin{array}{c}769 \neq \\
\{177(6)\}\end{array}$ & $\begin{array}{c}16.5 \\
\{3.8(6)\}\end{array}$ & $\begin{array}{l}13.9 \mathrm{~ns} \\
\{3.2(6)\}\end{array}$ \\
\hline & 150K-ms/150K-ms & $\begin{array}{c}-476 \neq \\
\{112(8)\}\end{array}$ & $\begin{array}{l}-429 \mathrm{~ns} \\
\{130(8)\}\end{array}$ & $\begin{array}{c}6.1 \neq \\
\{1.3(8)\}\end{array}$ & $\begin{array}{c}4.6 \mathrm{~ns} \\
\{1.3(8)\}\end{array}$ & $\begin{array}{l}-3.8 \neq \\
\{1.2(8)\}\end{array}$ & $\begin{array}{l}-3.6 \mathrm{~ns} \\
\{1.2(8)\}\end{array}$ & $\begin{array}{c}677 \mathrm{~ns} \\
\{218(8)\}\end{array}$ & $\begin{array}{c}625 \mathrm{~ns} \\
\{218(8)\}\end{array}$ & $\begin{array}{c}8.0 \mathrm{~ns} \\
\{2.5(8)\}\end{array}$ & $\begin{array}{c}6.8 \mathrm{~ns} \\
\{2.4(8)\}\end{array}$ \\
\hline \multirow[t]{3}{*}{$\begin{array}{c}\text { Series } 3 \\
\text { Benzamil } \mathrm{Na} / \mathrm{Li}\end{array}$} & 150Na-ms/150Na-ms & $\begin{array}{l}-1922 \\
\{96(5)\}\end{array}$ & $\begin{array}{c}-639 \neq \\
\{151(5)\}\end{array}$ & $\begin{array}{c}19.8 \\
\{1.1(5)\}\end{array}$ & $\begin{array}{c}5.9 \neq \\
\{2.1(5)\}\end{array}$ & $\begin{array}{c}0.7 \\
\{0.4(5)\}\end{array}$ & $\begin{array}{l}-0.3 \neq \\
\{0.5(5)\}\end{array}$ & $\begin{array}{c}2109 \\
\{153(5)\}\end{array}$ & $\begin{array}{c}1413 \neq \\
\{165(5)\}\end{array}$ & $\begin{array}{c}23.7 \\
\{1.6(5)\}\end{array}$ & $\begin{array}{c}20.3 \neq \\
\{1.7(5)\}\end{array}$ \\
\hline & 150Na-ms/150Li-ms & $\begin{array}{c}-1656 \\
\{126(5)\}\end{array}$ & $\begin{array}{l}-682 \neq \\
\{86(5)\}\end{array}$ & $\begin{array}{c}15.9 \\
\{1.3(5)\}\end{array}$ & $\begin{array}{c}6.5 \neq \\
\{0.7(5)\}\end{array}$ & $\begin{array}{c}6.3 \\
\{1.5(5)\}\end{array}$ & $\begin{array}{c}3.1 \neq \\
\{1.5(5)\}\end{array}$ & $\begin{array}{c}1619 \\
\{224(5)\}\end{array}$ & $\begin{array}{c}1203 \neq \\
\{144(5)\}\end{array}$ & $\begin{array}{c}18.9 \\
\{2.6(5)\}\end{array}$ & $\begin{array}{l}16.8 \mathrm{~ns} \\
\{1.8(5)\}\end{array}$ \\
\hline & & \multicolumn{2}{|c|}{ Benz $(-)$} & \multicolumn{2}{|c|}{ Benz $(-)$} & \multicolumn{2}{|c|}{ Benz $(-)$} & \multicolumn{2}{|c|}{ Benz $(-)$} & \multicolumn{2}{|c|}{ Benz $(-)$} \\
\hline \multirow[t]{3}{*}{$\begin{array}{l}\text { Series } 4 \\
\mathrm{Na}-\mathrm{Li}\end{array}$} & $150 \mathrm{Na}-\mathrm{ms} / 150 \mathrm{Na}-\mathrm{ms}$ & \multicolumn{2}{|c|}{$\begin{array}{c}-1416 \\
\{181(5)\}\end{array}$} & \multicolumn{2}{|c|}{$\begin{array}{c}14.1 \\
\{1.6(5)\}\end{array}$} & \multicolumn{2}{|c|}{$\begin{array}{c}0.1 \\
\{0.4(5)\}\end{array}$} & \multicolumn{2}{|c|}{$\begin{array}{c}1710 \\
\{218(5)\}\end{array}$} & \multicolumn{2}{|c|}{$\begin{array}{c}18.3 \\
\{2.1(5)\}\end{array}$} \\
\hline & 150Na-ms/150Li-ms & \multicolumn{2}{|c|}{$\begin{array}{l}-1699 \neq \\
\{149(5)\}\end{array}$} & \multicolumn{2}{|c|}{$\begin{array}{c}16.2 \neq \\
\{1.4(5)\}\end{array}$} & \multicolumn{2}{|c|}{$\begin{array}{c}7.1 \neq \\
\{1.2(5)\}\end{array}$} & \multicolumn{2}{|c|}{$\begin{array}{l}1840 \text { ns } \\
\{148(5)\}\end{array}$} & \multicolumn{2}{|c|}{$\begin{array}{l}21.3 \mathrm{~ns} \\
\{1.5(5)\}\end{array}$} \\
\hline & & Benz (-) & Benz (+) & Benz (-) & Benz (+) & Benz (-) & Benz (+) & Benz (-) & Benz (+) & Benz $(-)$ & Benz $(+)$ \\
\hline \multirow[t]{3}{*}{$\begin{array}{l}\text { Series } 5 \\
\text { All cations - benzamil }\end{array}$} & $15 \mathrm{Na}-\mathrm{ms} / 150 \mathrm{Na}-\mathrm{ms}$ & $\begin{array}{c}-3434 \\
\{363(5)\}\end{array}$ & $\begin{array}{l}-741 \neq \\
\{65(5)\}\end{array}$ & $\begin{array}{c}31.2 \\
\{3.3(5)\}\end{array}$ & $\begin{array}{c}6.1 \neq \\
\{0.9(5)\}\end{array}$ & $\begin{array}{c}29.8 \\
\{1.0(5)\}\end{array}$ & $\begin{array}{l}21.1 \neq \\
\{2.5(5)\}\end{array}$ & $\begin{array}{c}1666 \\
\{243(5)\}\end{array}$ & $\begin{array}{c}1039 \neq \\
\{162(5)\}\end{array}$ & $\begin{array}{c}25.7 \\
\{3.1(5)\}\end{array}$ & $\begin{array}{l}21.1 \neq \\
\{2.4(5)\}\end{array}$ \\
\hline & & \multicolumn{2}{|c|}{ Benz $(-)$} & \multicolumn{2}{|c|}{ Benz $(-)$} & \multicolumn{2}{|c|}{ Benz $(-)$} & \multicolumn{2}{|c|}{ Benz $(-)$} & \multicolumn{2}{|c|}{ Benz (-) } \\
\hline & 15Na-ms/150NMDG-ms & \multicolumn{2}{|c|}{$\begin{array}{c}-802 \neq \\
\{118(5)\}\end{array}$} & \multicolumn{2}{|c|}{$\begin{array}{c}11.3 \neq \\
\{1.4(5)\}\end{array}$} & \multicolumn{2}{|c|}{$\begin{array}{l}-27.8 \neq \\
\{3.6(5)\}\end{array}$} & \multicolumn{2}{|c|}{$\begin{array}{l}1834 \text { ns } \\
\{342(5)\}\end{array}$} & \multicolumn{2}{|c|}{$\begin{array}{c}17.0 \neq \\
\{3.0(5)\}\end{array}$} \\
\hline
\end{tabular}

Table entries are means on the top line and \{SEM (number of experiments)\} on the second line. Benz, benzamil; Benz(-), without benzamil; Benz(+), with benzamil $(1 \mu \mathrm{M})$.

$\mathrm{ms}$, Methanesulfonate, The number in front of chemical formula at [Pipette]/[Bath] is concentration (mM).

$\mathrm{I}(-100)$ and $\mathrm{g}(-)$, whole-cell patch clamp current and slope conductance at $-100 \mathrm{mV}$ command voltage; $\mathrm{Vr}$, reversal voltage; $\mathrm{I}(+100)$ and $\mathrm{g}(+)$, current and conductance at $+100 \mathrm{mV}$ command voltage.

Significant differences: $\neq, \mathrm{P}<0.05 ; \mathrm{ns}$, not significant.

Comparisons:

Series 1, 2, 3 and $5\left(\mathrm{Na}^{+}\right)$-Values in benzamil vs without benzamil (paired); Series 4-Values in $\mathrm{Li}^{+}$vs Na+ ; Series $5\left(\mathrm{NMDG}^{+}\right)-\mathrm{NMDG}^{+}$vs Na ${ }^{+}$(both in the absence of benzamil). In series 2, the symbols in the "Benz(+)" column report the significance of changes in values between \pm benzamil using the paired $\mathrm{t}$-test and the symbols in the "Benz(-)" column report the significance of changes in values between $\mathrm{K}^{+}$and $\mathrm{Na}{ }^{+}$using the

unpaired t-test. 
Table 2 Transcript analysis of amiloride-sensitive channel genes in Reissner's membrane

\begin{tabular}{|c|c|c|c|c|}
\hline $\begin{array}{c}\text { GenBank Accession } \\
\text { No. }\end{array}$ & Gene & Protein & $\begin{array}{l}\text { Call Gene } \\
\text { array* }\end{array}$ & $\begin{array}{c}\text { Call } \\
\text { qRT-PCR* }\end{array}$ \\
\hline AF112185 & Scnn1a & $\alpha \mathrm{ENaC}$ & $P$ & $P$ \\
\hline NM_011325 & Scnnib & $\beta \mathrm{ENaC}$ & $P$ & $P$ \\
\hline NM_011326 & Scnnig & $\gamma \mathrm{ENaC}$ & $P$ & $P$ \\
\hline NM_009597 & Accn2 & ASIC1a & $P^{* *}$ & A \\
\hline NM_001034013 & Accn 1 & ASIC2a & $A^{* *}$ & A \\
\hline NM_007384 & $A c c n 2 b$ & ASIC2b & $A^{* *}$ & A \\
\hline NM_183000 & Accn3 & ASIC3 & $P$ & ND \\
\hline NM_183022 & Accn4 & $\mathrm{ASIC} 4$ & A & ND \\
\hline NM_007723/U19717 & Cngal & CNGA1 & A & ND \\
\hline NM_007724 & Cnga2 & CNGA2 & $A$ & ND \\
\hline NM_009918 & Cnga3 & CNGA3 & $\mathrm{NL}$ & ND \\
\hline NM_001033317 & Cnga4 & CNGA4 & A & ND \\
\hline HQ_116386 & Cngbl & CNGB1 & $\mathrm{NL}$ & ND \\
\hline NM_013927 & Cngb3 & CNGB3 & A & ND \\
\hline NM_022017 & Trpv4 & TRPV4 & $P$ & $P$ \\
\hline NM_010408 & Henl & HCN1 & $P$ & A \\
\hline NM_008226 & $\mathrm{Hen} 2$ & HCN2 & $P$ & A \\
\hline NM_008227 & $\mathrm{Hcn} 3$ & HCN3 & $A$ & A \\
\hline NM_001081192 & Hen4 & $\mathrm{HCN} 4$ & $\mathrm{NL}$ & $A$ \\
\hline
\end{tabular}

${ }^{*}$ Call, gene was detected as present (P) or absent (A).

**Gene array annotation (Affymetrix \#31) does not distinguish ' $a$ ' and ' $b$ ' variants. ND, Not Done; NL, Not Listed in gene array.

$-476 \pm 112 \mathrm{pA}$ to $-429 \pm 130 \mathrm{pA}, \mathrm{n}=8)$. A representative experiment is shown in Figure 1 and a summary of similar experiments is shown in Figure 2 and Table 1.

$\mathrm{Li}^{+} / \mathrm{Na}^{+}$permeability ratio of benzamil-sensitive current The high $\mathrm{Na}^{+}$selectivity of the benzamil-sensitive current over $\mathrm{K}^{+}$suggested that $\mathrm{ENaC}$ might mediate part or all of that current. One salient characteristic of ENaC is a higher permeability to $\mathrm{Li}^{+}$than to $\mathrm{Na}^{+}$. We compared (Series 3,4) whole-cell currents in the presence of $\mathrm{Li}^{+}$and $\mathrm{Na}^{+}$in the bath and the effects of benzamil. The comparisons were conducted in two series of paired measurements from the same experimental data set in order to minimize the effects of rundown. In the first series of measurements (Series 3), inward Li currents were tested for sensitivity to benzamil. A representative experiment is shown in Figure 3A and its I-V releationship in Figure 3B. The I-V relationships were very similar for both $\mathrm{Na}^{+}$(B2) and $\mathrm{Li}^{+}$(B4) and benzamil markedly decreased the inward currents for both ions. Specifically, benzamil significantly inhibited the inward $\mathrm{Li}^{+}$whole-cell current (at $-100 \mathrm{mV}$ ) by $58.8 \%$; from $\mathrm{I}_{-100}=$ $-1656 \pm 126 \mathrm{pA}$ to $-682 \pm 86 \mathrm{pA}(\mathrm{n}=5)$ (Figure $3 \mathrm{~B}, \mathrm{C}$ and Table 1). Similarly, benzamil decreased (Series 3 ) the inward $\mathrm{Na}^{+}$current at $-100 \mathrm{mV}$ by $66.8 \%$ (from $\mathrm{I}_{-100}=$ $-1922 \pm 96 \mathrm{pA}$ to $-639 \pm 151 \mathrm{pA}$ ), a decrease that was not significantly different from the decrease by benzamil seen in the previous series (Series 2) of experiments with $\mathrm{Na}^{+}$ in the bath (Figure 3B and Table 1).

It was to be expected that there would be no change in the observed $V_{r}$ between the presence and absence of benzamil since the reversal potential for both $\mathrm{Na}^{+}$-selectective and NSC channels are both $=0$. By contrast, if $\mathrm{Li}^{+}$is more permeable than $\mathrm{Na}^{+}, \mathrm{V}_{\mathrm{r}}$ would be expected to become more positive (see second series, below).

In the second series of measurements (Series 4), $\mathrm{Na}^{+}$ and $\mathrm{Li}^{+} \mathrm{I}-\mathrm{V}$ relationships were compared immediately before and after the solution change (points 3 and 4 ' in Figure 3A). Rapid change of the bath solution from a $\mathrm{Na}^{+}$-rich solution (B2) to a $\mathrm{Li}^{+}$-rich solution (B4) led to small but consistent changes in the current. The average inward current and conductance at large negative voltage $(-100 \mathrm{mV})$ were significantly larger for $\mathrm{Li}^{+}$than for $\mathrm{Na}^{+}$, by $19.9 \%\left(\mathrm{I}_{-100}=-1699 \pm 149 \mathrm{pA} v s-1416 \pm 181 \mathrm{pA}\right.$, $\mathrm{n}=5)$ and $14.9 \%\left(\mathrm{~g}_{-100}=16.2 \pm 1.4 \mathrm{nS}\right.$ vs $14.1 \pm 1.6 \mathrm{nS}$, $\mathrm{n}=5$ ). Further, the reversal voltage was significantly more positive $(7.1 \pm 1.2 \mathrm{mV}$ vs $0.1 \pm 0.4 \mathrm{mV})$ (Figure 4).

The shift in $\mathrm{V}_{\mathrm{r}}$ was analyzed with the Goldman-HodgkinKatz (GHK) equation as applied to bionic substitutions to estimate the relative membrane permeability to $\mathrm{Li}^{+}$and $\mathrm{Na}^{+}[12]$ :

$$
\Delta V_{r}=\frac{R T}{z F} \operatorname{In} \frac{P_{L i}[L i]_{o}}{P_{N a}[N a]_{o}},
$$

where $\Delta V_{r}$ is the change in reversal potential, $R$ the universal gas constant, $\mathrm{T}$ the absolute temperature, $\mathrm{z}$ the valence, $\mathrm{F}$ the Faraday constant, $[\mathrm{Li}]_{\mathrm{o}}$ the extracellular $\mathrm{Li}^{+}$concentration, $[\mathrm{Na}]_{\mathrm{o}}$ the extracellular $\mathrm{Na}^{+}$ concentration and $\mathrm{P}_{\mathrm{Li}}$ and $\mathrm{P}_{\mathrm{Na}}$ the permeabilities of the membrane for $\mathrm{Li}^{+}$and $\mathrm{Na}^{+}$. The shift of $\mathrm{V}_{\mathrm{r}}$ by 7.0 $\mathrm{mV}$ in the current study corresponds to a $\mathrm{P}_{\mathrm{Li}} / \mathrm{P}_{\mathrm{Na}}$ ratio of 1.3. This result is within the range of reports by others for the ratio in $\alpha \beta \gamma-\mathrm{ENaC}(1.3[13,14], 1.6$ [11], $1.8[15])$.

\section{Benzamil-insensitive cation channels}

We hypothesized that the residual current after inhibition by benzamil could be transported through nonselective cation channels, although a substantial contribution of NSC channels was unlikely since $\mathrm{K}^{+}$ conductance was relatively small. Alternatively, the residual current could be a patch leakage current.

It was first observed that transcripts of TRPV4, an amiloride-insensitive NSC channel, were present by both gene array and RT-PCR (Table 2). The amilorideinsensitive channels HCN1-4 are permeable to $\mathrm{K}^{+}$and $\mathrm{Na}^{+}\left(\mathrm{P}_{\mathrm{K}} / \mathrm{P}_{\mathrm{Na}} \sim 4[16]\right)$ and were found to be absent by RT-PCR, although some false positives in the gene array were found (Table 2). 


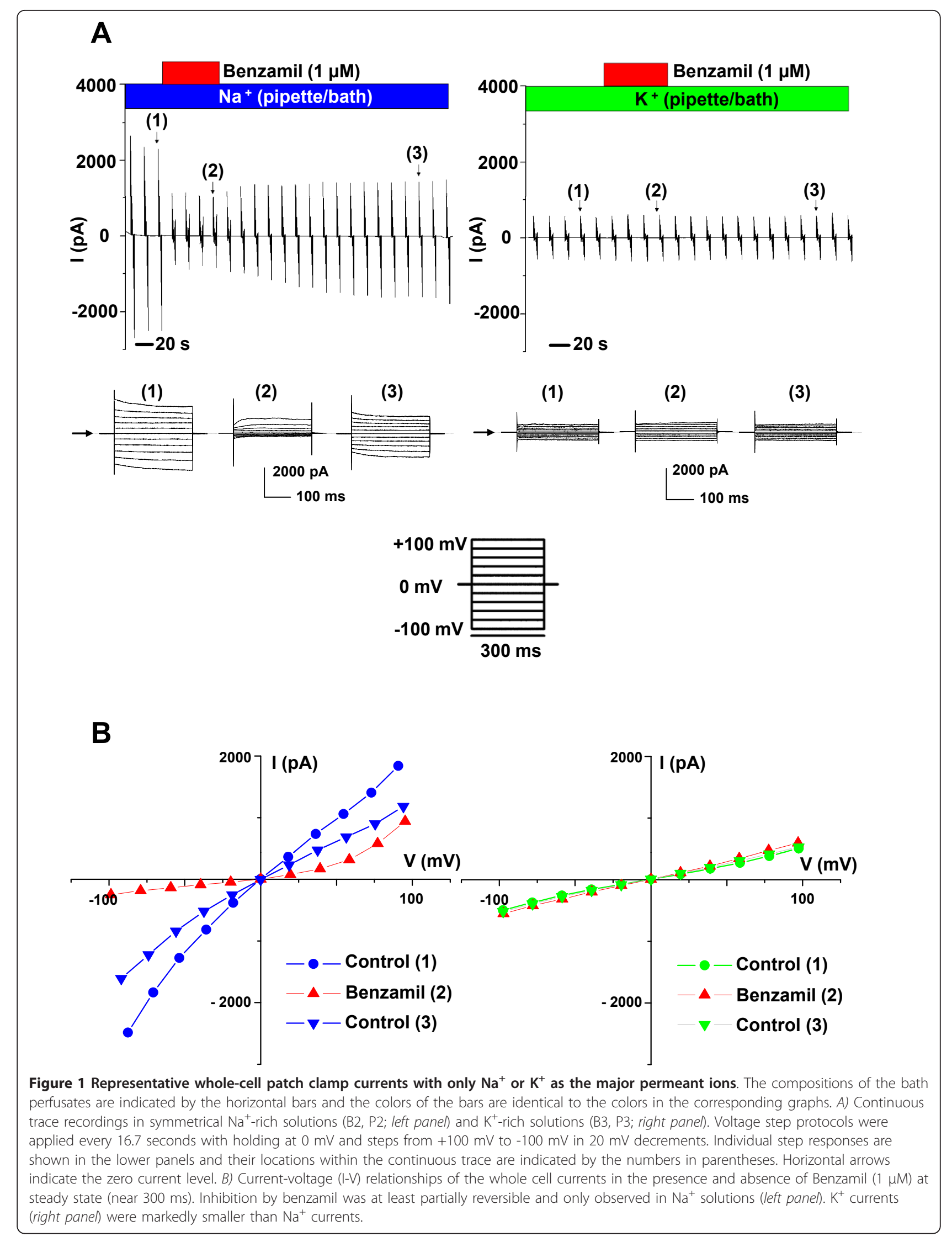



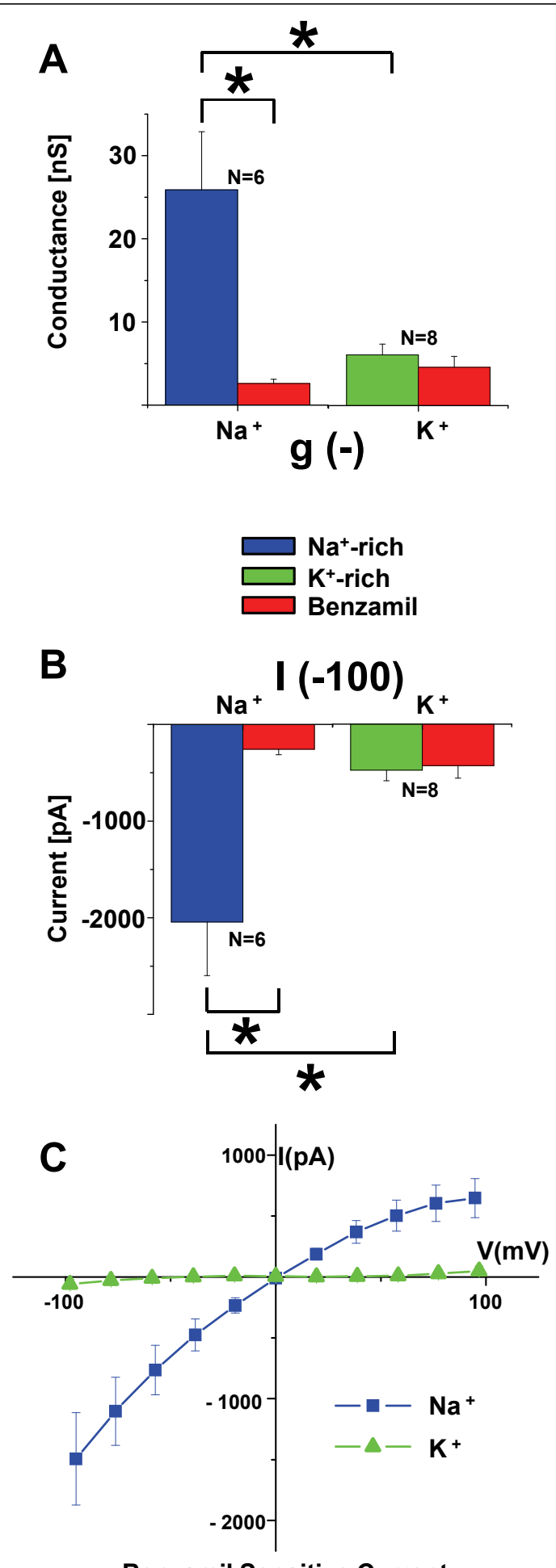

Benzamil Sensitive Current

Figure 2 Summary of whole-cell patch clamp currents with only $\mathrm{Na}^{+}$or $\mathrm{K}^{+}$as the major permeant ions. A) Bar graph of the conductances and B) currents at $-100 \mathrm{mV}$ in symmetrical $\mathrm{Na}^{+}$-rich solutions (B2, P2) and $\mathrm{K}^{+}$-rich solutions (B3, P3). C) Current-voltage $(\mathrm{I}-\mathrm{V})$ relationships of the Benzamil-sensitive current at steady state (near $300 \mathrm{~ms}$ ). Benzamil-sensitive current was only observed in $\mathrm{Na}^{+}$ solutions. $\mathrm{K}^{+}$currents were markedly smaller than $\mathrm{Na}^{+}$currents.
We tested for the presence of benzamil-insensitive currents by comparing the inward current in the presence and absence of benzamil with a substitution of the impermeable cation $\mathrm{NMDG}^{+}$for $\mathrm{Na}^{+}$in the bath.

In this series of experiments (Series 5), the initial phase before benzamil did not quickly reach a stable condition so that parameters in benzamil were compared to those after washout. Nonetheless, it is clear that the inward current and conductance in benzamil were significantly less than the inward $\mathrm{Na}^{+}$current and conductance after washout (Figure 5, Table 1). Importantly, there was no significant difference between the inward current in benzamil $\left(\mathrm{I}_{-100}=-741 \pm 65 \mathrm{pA}, \mathrm{n}=\right.$ $5)$ and in $\mathrm{NMDG}^{+}\left(\mathrm{I}_{-100}=-802 \pm 118 \mathrm{pA}, \mathrm{n}=5, \mathrm{~B} 5\right)$. These results demonstrate that there were no cation currents other than the benzamil-sensitive channels under these conditions.

$\mathrm{Na}^{+}$in the pipette was reduced to $15 \mathrm{mM}$ (P4) in order to confirm the $\mathrm{Na}^{+}$-selectivity of the current in this experimental series. The large decrease in $\mathrm{V}_{\mathrm{r}}$ between $\mathrm{Na}^{+}$(B2) and $\mathrm{NMDG}^{+}$(B5) (from $29.8 \pm 1.0 \mathrm{mV}$ to $-27.8 \pm 3.6 \mathrm{mV}$, $\mathrm{n}=5$; Figure 5 and Table 1 ) is consistent with a large $\mathrm{Na}^{+}$ conductance. The small, but significant, decrease in $\mathrm{V}_{\mathrm{r}}$ between \pm benzamil could conceivably be due to the presence of an $\mathrm{H}^{+}$conductance and the small $\mathrm{pH}$ gradient between intra- and extracellular solutions. The equilibrium potential for $\mathrm{Na}^{+}$was $+60 \mathrm{mV}$ and for $\mathrm{H}^{+}$was $+6 \mathrm{mV}$. The absence of any significant difference (Table 1) in $\mathrm{I}_{+100}(14834 \pm 342 \mathrm{pA}$ vs $1666 \pm 243 \mathrm{pA}, \mathrm{n}=5)$ in $\mathrm{NMDG}^{+}$and $\mathrm{Na}^{+}$baths (B5 and B2) is consistent with the current at $+100 \mathrm{mV}$ being carried predominantly by the efflux of intracellular $\mathrm{Na}^{+}$, since the pipette concentration (P4) remained the same for both bath solutions.

\section{Discussion}

Active $\mathrm{Na}^{+}$absorption is needed to remove $\mathrm{Na}^{+}$that has entered cochlear endolymph through as-yet-undefined pathways. Elevated $\mathrm{Na}^{+}$would provide an osmotic driving force for water entry that would lead to endolymphatic hydrops, a pathologic swelling of the luminal space. In addition, the cochlear epithelium requires parasensory $\mathrm{K}^{+}$-efflux pathways to compensate for changes in $\mathrm{K}^{+}$efflux through sensory hair cells during changes in auditory stimulation.

In addition to $\mathrm{Na}^{+}$and $\mathrm{K}^{+}$absorption from endolymph via the outer sulcus cells in the cochlear lateral wall [17], Reissner's membrane epithelium has been found to actively absorb $\mathrm{Na}^{+}$from endolymph via amiloride- and benzamil-sensitive pathways. This transport was thought to be mediated by the epithelial $\mathrm{Na}^{+}$channel $(\mathrm{ENaC})$ in the apical membrane of these cells $[4,5]$.

The classical $\mathrm{ENaC}$ is highly selective to the passage of $\mathrm{Na}^{+}$over $\mathrm{K}^{+}\left(\mathrm{P}_{\mathrm{Na}} / \mathrm{P}_{\mathrm{K}}>80\right)$. However, there are reports of poorly-selective epithelial $\mathrm{Na}^{+}$absorptive pathways 
Table 3 Bath and pipette solutions (mM)

\begin{tabular}{|c|c|c|c|c|c|c|c|c|c|}
\hline \multirow{3}{*}{ Solution } & \multicolumn{5}{|c|}{ Bath } & \multicolumn{4}{|c|}{ Pipette } \\
\hline & $\mathrm{NaCl}$-rich & Na-rich & K-rich & Li-rich & NMDG-rich & KCl-rich & Na-rich & K-rich & $\mathrm{NMDG}+\mathrm{Na}$ \\
\hline & B1 & B2 & B3 & B4 & B5 & P1 & P2 & P3 & P4 \\
\hline $\mathrm{NaCl}$ & 150 & & & & & 10 & & & \\
\hline $\mathrm{KCl}$ & 4 & & & & & 140 & & & \\
\hline $\mathrm{MgCl} 2$ & 1 & & & & & 1 & & & \\
\hline $\mathrm{CaCl} 2$ & 0.7 & & & & & 0.273 & & & \\
\hline glucose & 5 & 5 & 5 & 5 & 5 & & & & \\
\hline HEPES & 10 & 10 & 10 & 10 & 10 & 10 & 10 & 10 & 10 \\
\hline EGTA & & & & & & 1 & 1 & 1 & 1 \\
\hline $\mathrm{Na}-\mathrm{ms}^{*}$ & & 150 & & & & & 150 & & 15 \\
\hline $\mathrm{K}-\mathrm{ms}^{*}$ & & & 150 & & & & & 150 & \\
\hline Li-ms* & & & & 150 & & & & & \\
\hline NMDG-ms* & & & & & 150 & & & & 135 \\
\hline Ca-gluconate & & 0.7 & 0.7 & 0.7 & 0.7 & & 0.367 & 0.367 & 0.367 \\
\hline $\mathrm{MgSO} 4$ & & 1 & 1 & 1 & 1 & & 1 & 1 & 1 \\
\hline adjusted by & $\mathrm{NaOH}$ & $\mathrm{NaOH}$ & $\mathrm{KOH}$ & $\mathrm{LiOH}$ & NMDG & $\mathrm{KOH}$ & $\mathrm{NaOH}$ & $\mathrm{KOH}$ & NMDG \\
\hline $\mathrm{pH}$ & 7.4 & 7.4 & 7.4 & 7.4 & 7.4 & 7.2 & 7.3 & 7.3 & 7.3 \\
\hline
\end{tabular}

*ms: Methanesulfonate.

under some culture conditions and this can be due to either altered $\mathrm{ENaC}$ subunit stoichiometry or increased expression of unrelated nonselective cation channels [18]. Heteromeric channels composed of the $\alpha-, \beta-$ and $\gamma-\mathrm{ENaC}$ subunits are highly $\mathrm{Na}^{+}$-selective, while homomeric $\alpha-\mathrm{ENaC}$ channels are also permeable to $\mathrm{K}^{+}$[18]. Homo- and hetero-meric ENaC are pharmacologically defined by their inhibition by amiloride and its analogs [19]. All $3 \mathrm{ENaC}$ subunits are expressed in Reissner's membrane [5], but the stoichiometric subunit association in the apical membrane of Reissner's membrane epithelial cells is not known. In addition, other cation channels such as acid sensitive ion channels (ASIC) and cyclic nucleotide gated channels (CNG) have been observed to be sensitive to amiloride and benzamil (micromolar to submicromolar range) $[20,21]$.

A vestige of doubt therefore remained whether the benzamil-sensitive current could also carry $\mathrm{K}^{+}$as well as $\mathrm{Na}^{+}$.

We tested the hypothesis that the benzamil-sensitive $\mathrm{Na}^{+}$absorption pathway in Reissner's membrane could also carry a $\mathrm{K}^{+}$current. Our results showed the absence of transcript expression of many candidate nonselective cation channels and the functional absence of both benzamil-sensitive and -insensitve nonselective cation currents. The results demonstrated a high selectivity of the benzamil-sensitive pathway to $\mathrm{Na}^{+}$over $\mathrm{K}^{+}$.

One further test of the molecular identity of the benzamil-sensitive pathway was a comparison of the permeability to $\mathrm{Li}^{+}$and $\mathrm{Na}^{+}$. The greater permeability to $\mathrm{Li}^{+}$is consistent with the benzamil-sensitive current carried by the classical $\alpha \beta \gamma-\mathrm{ENaC}$.

\section{Conclusions}

The results of this study support the conclusion that the benzamil-sensitive whole-cell current in Reissner's membrane epithelial cells is highly selective for $\mathrm{Na}^{+}$and does not support the transport of $\mathrm{K}^{+}$. When this is combined with the results of previous studies on the benzamilsensitive transepithelial current, it suggests that Reissner's membrane contributes to maintaining the low $\mathrm{Na}^{+}$concentration in normal endolymph but is not involved in $\mathrm{K}^{+}$ homeostasis through this pathway (Figure 6).

\section{Methods}

Tissue preparation for electrophysiological recordings

Tissue was obtained, prepared and analyzed as described previously [22]. Mice (C57BL/6) were anesthetized with $4 \%$ tribromoethanol $(0.014 \mathrm{ml} / \mathrm{g}$ body wt ip) and killed following a protocol approved by the Institutional Animal Care and Use Committee of Kansas State University. The lateral wall of the cochlear apical turn was isolated from the temporal bone, the stria vascularis removed and Reissner's membrane was gently pushed into the same plane as the spiral ligament. Reissner's membrane consists of an epithelial cell layer facing the endolymph and a mesothelial cell layer facing the perilymph, the two layers being separated by a basement membrane. The tissue was folded with the apical membrane of the epithelium on the exterior of the loop in order to form patch clamp seals with the apical membrane (Additional file 1: Fig. S3).

\section{Whole cell patch clamp recording}

Currents were recorded using the whole-cell configuration of the patch clamp technique, similar to our 


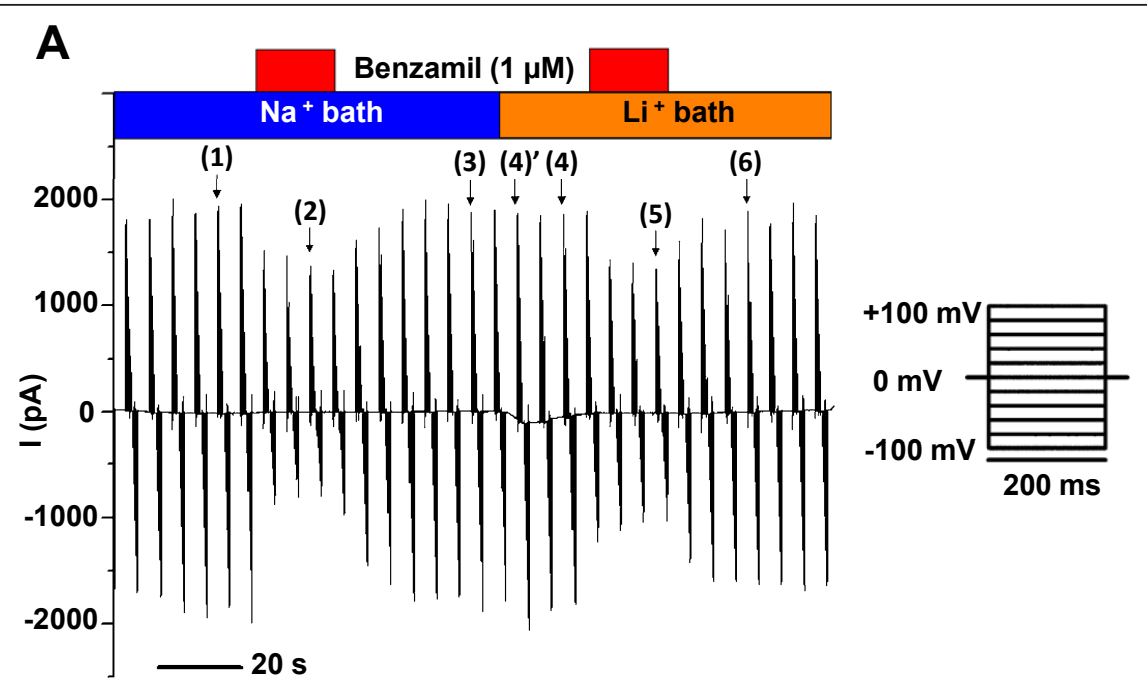

(1)

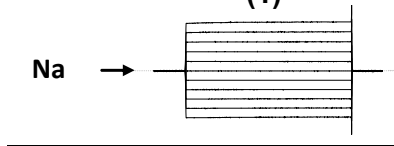

(4)
(2)

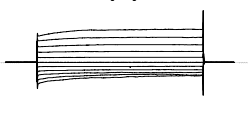

(5)

(3)

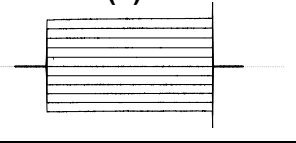

(6)
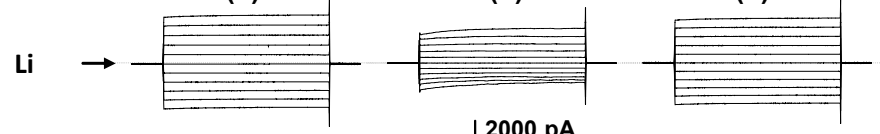

$100 \mathrm{~ms}$

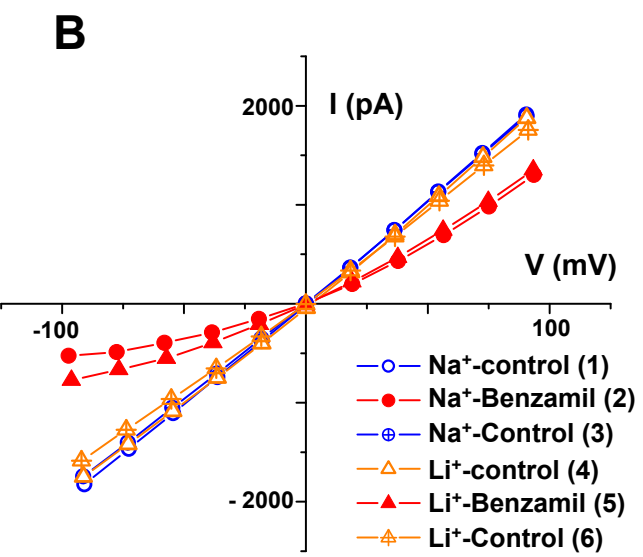

I-V curve
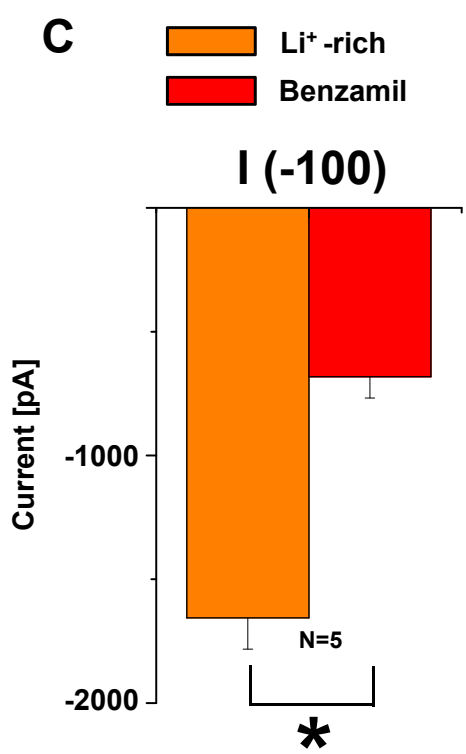

Figure 3 Whole-cell patch clamp currents with only $\mathrm{Na}^{+}$or $\mathrm{Li}^{+}$as the major permeant ions. The compositions of the bath perfusates are indicated by the horizontal bars and the colors of the bars are identical to the colors in the corresponding graphs. A) Representative continuous recording in symmetrical $\mathrm{Na}^{+}$-rich solutions (B2, P2; left panel) and $\mathrm{Li}^{+}$-rich solutions (B4, P2; right panel). Voltage step protocols were applied every 5.3 seconds with holding at $0 \mathrm{mV}$ and steps from $+100 \mathrm{mV}$ to $-100 \mathrm{mV}$ in $20 \mathrm{mV}$ decrements. Individual step responses are shown in the lower panels and their locations within the continuous trace are indicated by the numbers in parentheses. B) Representative current-voltage (I-V) relationships of the whole cell currents in the presence and absence of Benzamil $(1 \mu \mathrm{M})$ at steady state (near $200 \mathrm{~ms})$. The I-V relationship in Li ${ }^{+}$ bath was qualitatively similar to that in $\mathrm{Na}^{+}$bath, as was the response to benzamil $(1 \mu \mathrm{M})$.C) Summary bar graph of the currents at -100 $\mathrm{mV}$ in $\mathrm{Li}^{+}$-rich bath and $\mathrm{Na}^{+}$-rich pipette solutions (B4, P2). 


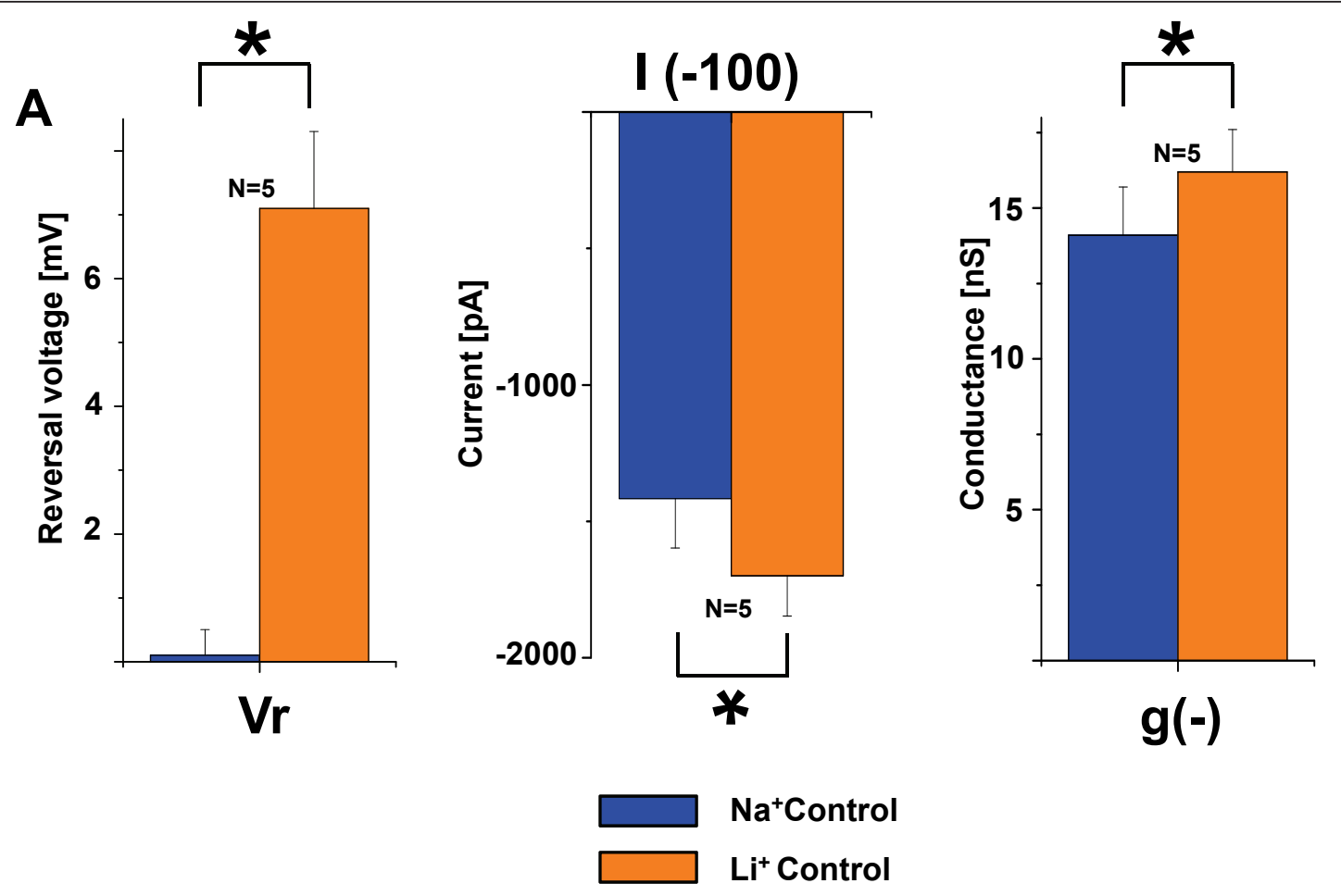

B

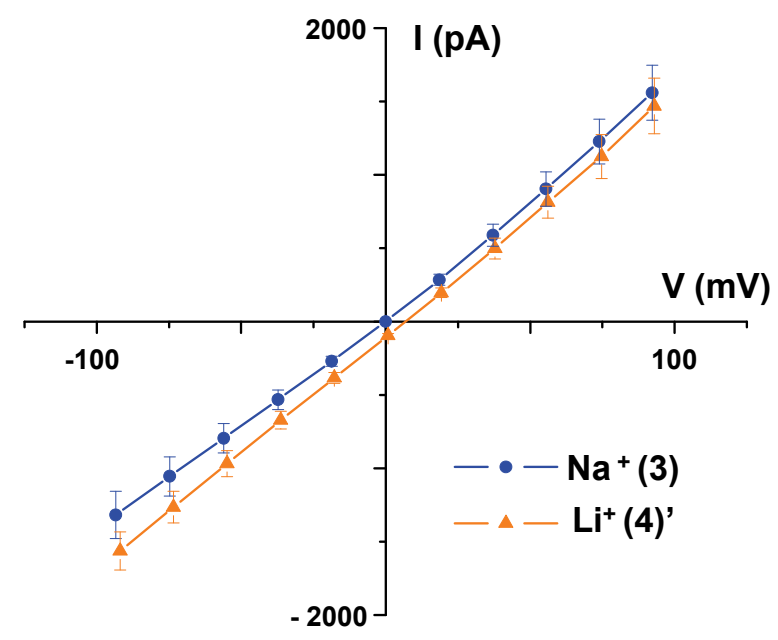

\section{I-V curve}

Figure 4 Summary whole-cell patch clamp currents and reversal voltage with only $\mathrm{Na}^{+}$or $\mathrm{Li}^{+}$as the major permeant ions. A) Bar graph of the reversal voltage (left panel), the currents at -100 mV (middle panel) and the conductance at -100 $\mathrm{mV}$ (right panel) in $\mathrm{Na}^{+}$-rich symmetrical solutions (B2, P2) and $\mathrm{Li}^{+}$-rich bath and $\mathrm{Na}^{+}$-rich pipette solutions (B4, P2). Data were taken from the rapid transition between $\mathrm{Na}^{+}$-rich and $\mathrm{Li}^{+}$-rich bath (time points 3 and $4^{\prime}$ in Fig 3A) in order to minimize the contribution of rundown. B) Summary of current-voltage (I-V) relationships of the whole cell currents in symmetrical $\mathrm{Na}^{+}$-rich solutions (B2, P2) and $\mathrm{Li}^{+}$-rich bath and $\mathrm{Na}^{+}$-rich pipette solutions (B4, P2) at steady state (near $200 \mathrm{~ms}$ ). 


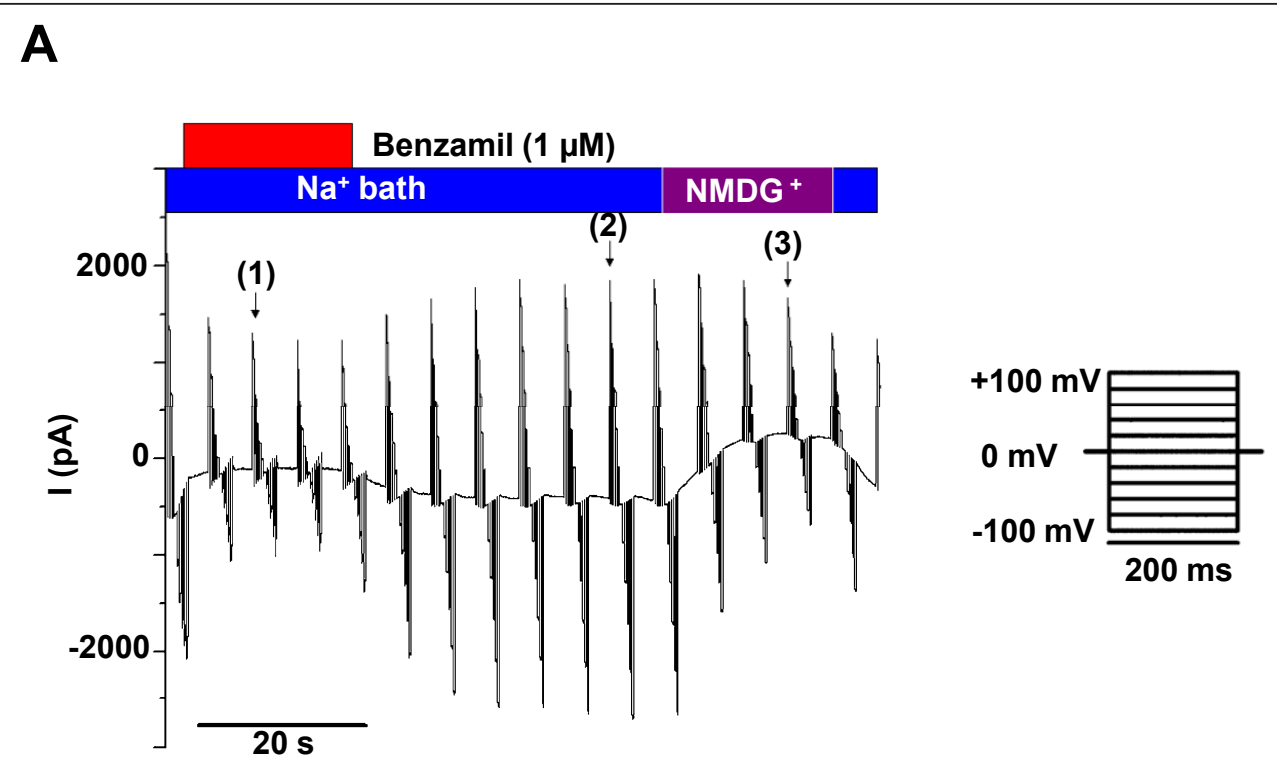

(1)

(2)

(3)

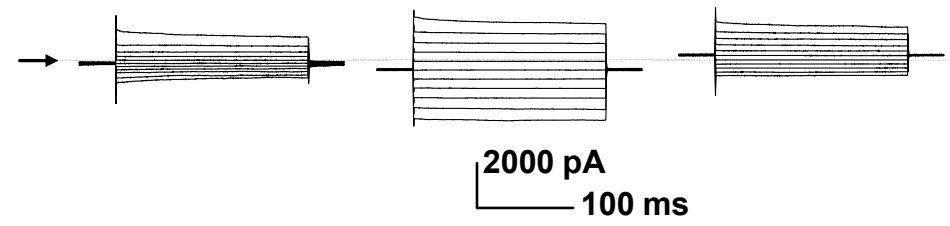

I (-100)
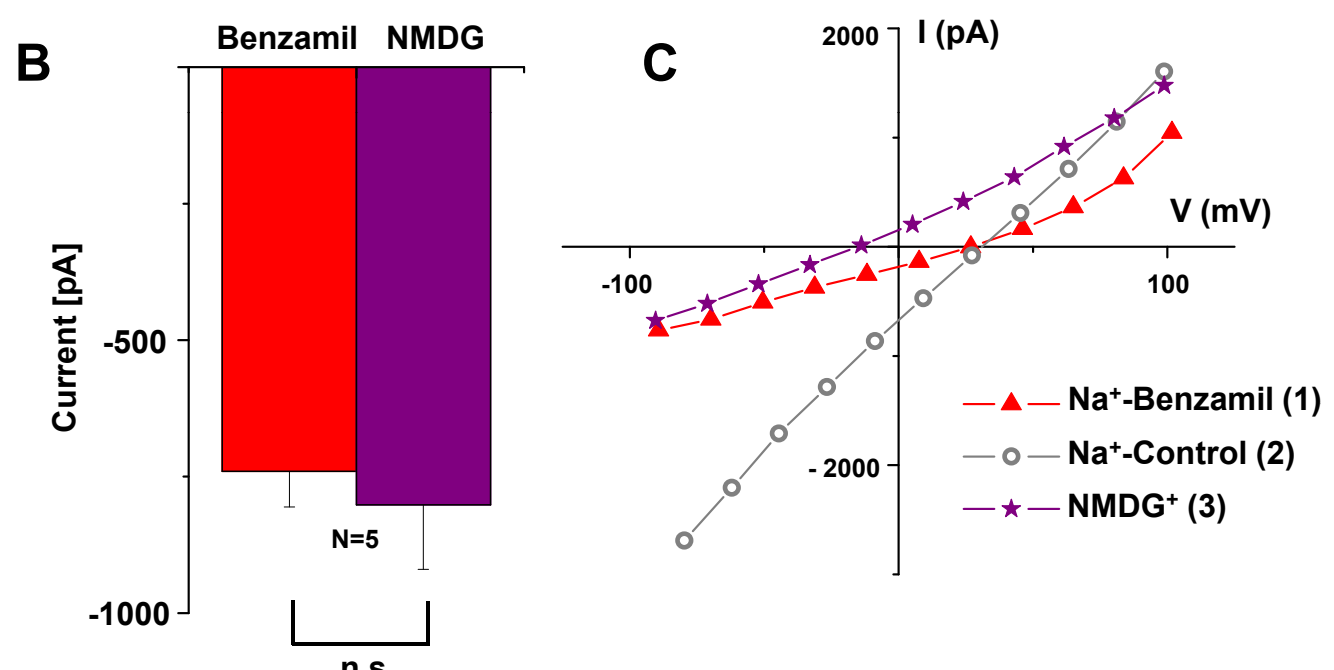

n.s.

Figure 5 Whole-cell patch clamp currents with only $\mathrm{Na}^{+}$or $\mathrm{NMDG}^{+}$as the major permeant ions. The compositions of the bath perfusates are indicated by the horizontal bars and the colors of the bars are identical to the colors in the corresponding graphs. A) Representative continuous trace recordings in the presence and absence of Benzamil $(1 \mu \mathrm{M})$ in Na${ }^{+}$-rich bath and $15 \mathrm{mM} \mathrm{Na}^{+}$pipette solutions (B2, P4) and $\mathrm{NMDG}^{+}$-rich bath and $15 \mathrm{mM} \mathrm{Na}^{+}$pipette solutions (B5, P4). Voltage step protocols were applied every 5.3 seconds with holding at $0 \mathrm{mV}$ and steps from $+100 \mathrm{mV}$ to $-100 \mathrm{mV}$ in $20 \mathrm{mV}$ decrements. Individual step responses are shown in the lower panels and their locations within the continuous trace are indicated by the numbers in parentheses. B) Summary bar graph of the currents at $-100 \mathrm{mV}$ in $\mathrm{Na}^{+}$-rich bath (B2) with Benzamil $(1 \mu \mathrm{M})$ and $\mathrm{NMDG}^{+}$-rich bath solutions (B5). C) Representative current-voltage (I-V) relationships of the whole cell currents in the presence and absence of Benzamil $(1 \mu \mathrm{M})$ in $\mathrm{Na}^{+}$-rich bath and $15 \mathrm{mM} \mathrm{Na}^{+}$pipette solutions (B2, P4) and $\mathrm{NMDG}^{+}$-rich bath and $15 \mathrm{mM} \mathrm{Na}^{+}$ pipette solutions (B5, P4) at steady state (near $200 \mathrm{~ms})$. NMDG ${ }^{+}$reduced the inward current $(-100 \mathrm{mV}$ ) by the same amount as did benzamil, and there was no difference between outward current $\left(+100 \mathrm{mV}\right.$ ) in $\mathrm{NMDG}^{+}$- and $\mathrm{Na}^{+}$-rich baths (B5 and B2). 


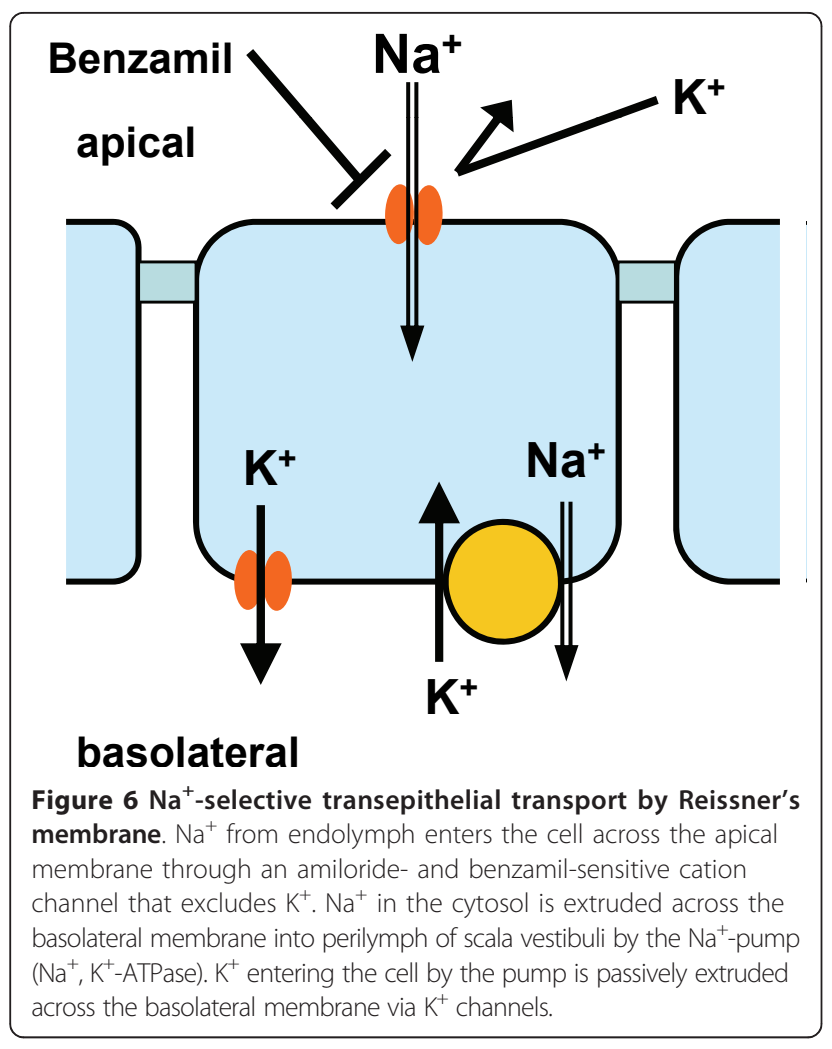

previous study [22]. Patch pipettes were made from borosilicate glass capillaries (1B150F; World Precision Instruments, Sarasota, FL), pulled in three stages with an electrode puller (Narishige, East Meadow, NY). Inner diameter of the tip was approximately $2 \mu \mathrm{m}$ and after heat polishing the pipettes had resistances of 3.3 9.6 $\mathrm{M} \Omega(\mathrm{n}=31)$ in the different bath solutions.

Currents were recorded with an Axopatch 200A amplifier (Axon Instruments, Foster City, CA) and lowpass filtered at $1 \mathrm{kHz}$. Current signals were digitized at $5 \mathrm{kHz}$ using a computer with a Digidata 1322A (Axon Instruments) and pCLAMP 9 software (clampex9, Axon Instruments) was used for voltage step protocol recordings. In addition, AxoScope software (Axon Instruments) with MiniDigi $1 \mathrm{~A}$ (Axon Instruments) data acquisition hardware was simultaneously used for continuous trace recordings and current signals were digitized at $1 \mathrm{kHz}$. The temperature was maintained at $37^{\circ} \mathrm{C}$ on a glass-bottomed bath chamber by a continuous, warmed perfusion and supplemental chamber heater.

For the pipette solution containing high $\mathrm{K}^{+}$(P3) and bath containing high $\mathrm{Na}^{+}$(B2), the data were corrected for the liquid junction potential of $4.1 \mathrm{mV}$. For the pipette solution containing low $\mathrm{Na}^{+}$and high $\mathrm{NMDG}^{+}$(P4) and baths containing high $\mathrm{Na}^{+}$(B2) and high $\mathrm{NMDG}^{+}$ (B5), the data were corrected for the liquid junction potentials of $-6.9 \mathrm{mV}$ and $-6.2 \mathrm{mV}$ (the latter includes the liquid junction potential change of $0.7 \mathrm{mV}$ at the reference electrode). Liquid junction potentials in symmetric Na-Methanesulfonate, K-Methanesulfonate, NMDG-Methanesulfonate were near zero, since voltage offset was adjusted when the pipette was immersed in each bath solution. The $\mathrm{Li}^{+}$data were corrected by adding the $0.3 \mathrm{mV}$ junction potential change at the reference electrode.

Two voltage protocols were used. Protocol 1: A series of pulses were applied for $300 \mathrm{~ms}$ each from a holding potential of $0 \mathrm{mV}$ to steps from +100 to $-100 \mathrm{mV}$ in $20 \mathrm{mV}$ decrements. The protocol was repeated every 16.7 s. Current-voltage (I-V) relationships were determined from averaging $30 \mathrm{~ms}$ of steady-state currents near the end of each voltage step. Protocol 2: This series only differed from the first protocol by the step duration $(200 \mathrm{mS})$ and the repetition rate $(5.3 \mathrm{~s})$. The I-V relationships were obtained from these current averages plotted against the command voltage, corrected for the liquid junction potential and an estimate of the voltage drop across the pipette resistance. These corrected curves were used to obtain the currents and conductances at $\pm 100 \mathrm{mV}\left(\mathrm{I}_{-100}, \mathrm{I}_{+100}, \mathrm{~g}_{+100}\right.$ and $\left.\mathrm{g}_{-100}\right)$ and the reversal voltage, $\mathrm{V}_{\mathrm{r}}$ (Additional file 1: Fig. S4). Data were plotted with Origin software, version 7 (OriginLab Software, Northampton, MA).

\section{Solutions and chemicals}

Table 3 shows the composition of the solutions of pipette and bath for electrophysiological recordings. The osmolarity of these solutions was about 311-318 mOsm. Benzamil (Sigma \#B-2417) was predissolved (1 $\mathrm{mM})$ in dimethylsulfoxide (DMSO), and was used at a final concentration of $1 \mu \mathrm{M}$ benzamil and 0.1\% DMSO. Pipette solutions (P1, P2, P3, P4) were buffered to $100 \mathrm{nM}$ free $\mathrm{Ca}^{2+}$ [23]. The KCl-rich pipette solution (P1) was adjusted to $\mathrm{pH} 7.3$ at room temperature, which corresponds to about 7.2 at $37^{\circ} \mathrm{C}$ and alters the $\mathrm{Ca}^{2+} /$ EGTA ratio at that elevated temperature. Pipettes using P2, P3 and $\mathrm{P} 4$ were backfilled with $15 \mathrm{mM} \mathrm{Cl}^{-}$substituted for methanesulfonate in order to make stable contact with the $\mathrm{Ag} / \mathrm{AgCl}$ electrode. The backfill solutions contained the dye fast green to visualize the interface with the tip solution, which filled the first $10 \mathrm{~mm}$ of the pipette. All pipette solutions for patch clamp were passed through $0.22 \mu \mathrm{m}$ cellulose acetate filters (Corning).

\section{RNA isolation for RT-PCR}

Four mice (C57BL/6, 4-10 weeks old) were anesthetized with $4 \%$ tribromoethanol $(0.014 \mathrm{ml} / \mathrm{g}$ body wt ip) and killed for each collection of total RNA. The two temporal bones were removed from each mouse after a transcardial perfusion of a phosphate-buffered saline (PBS) solution to reduce both cell swelling and contamination from blood cells. Reissner's membrane was 
dissected in PBS, which was changed twice during isolation of Reissner's membrane to reduce cross contamination from other tissues. All procedures were approved by the Institutional Animal Care and Use Committee of Kansas State University. Total RNA was isolated from the tissue using an RNeasy Micro Kit with carrier RNA (Qiagen, Valencia, CA). RNA used as positive control was from mouse kidney, mouse brain (Ambion, Austin, TX). The quality and quantity of RNA were determined with a Bioanalyzer (Additional file 1: Fig. S3B; Agilent, Palo Alto, CA). RT-PCR was conducted as described before [22].

\section{Statistical analysis}

Data were expressed as the mean \pm S.E.M. ( $\mathrm{n}=$ number of whole cell patches). Increases and decreases in current and conductance were determined by Student's paired or unpaired t-test as appropriate for the specific data sets. Differences were considered statistically significant at a level of $\mathrm{P}<0.05$ (Microsoft Excel).

\section{Additional material}

Additional file 1: Fig. S1, S2, S3, S4. Benzamil-sensitive whole cel patch clamp currents under quasi-physiologic conditions (representative experiment and data summary), illustration of the patch clamp preparation and the quality of total RNA collected from Reissner's membrane, and illustrative description of the correction of command voltages in I-V plots.

\section{Acknowledgements}

This work was supported by NIH grants R01-DC00212 and P20-RR017686 to DCM. We thank Dr. Philine Wangemann for helpful discussions.

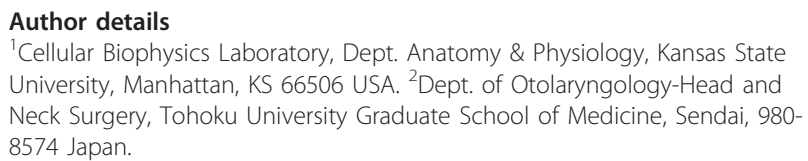

\section{Authors' contributions}

MY carried out the study on Reissner's membrane, including microdissection of tissues and patch clamp recordings, and contributed to writing the manuscript. KXK carried out the study on Reissner's membrane, including microdissection of tissues, primer design and validation, RNA isolation, quantitative analyses of PCR, preliminary patch clamp recordings and contributed to writing the manuscript. DCM conceived of the study, and participated in its design and coordination and contributed to writing the manuscript. All authors have read and approved the final manuscript.

\section{Authors' information}

MY is a clinician/researcher in the Dept. of Otolaryngology-Head and Neck Surgery at Tohoku University who conducted this research in partial fulfillment of requirements for the PhD degree at the Tohoku University Graduate School of Medicine. KXK contributed to this work while a candidate for a Masters degree at Kansas State University and upon completion of the requirements for the Master of Science degree, she has become a doctoral candidate in the Neuroscience Training Program at the University of Wisconsin. DCM is a University Distinguished Professor at Kansas State University in the Dept. of Anatomy \& Physiology and heads the Cellular Biophysics Laboratory.
Received: 22 October 2010 Accepted: 1 February 2011

Published: 1 February 2011

\section{References}

1. Marcus DC, Wangemann P: Inner ear fluid homeostasis. In The Oxford Handbook of Auditory Science: The Ear. Edited by: Fuchs PA. Oxford: Oxford University Press; 2010:213-230.

2. Marcus DC, Wangemann P: Cochlear and Vestibular Function and Dysfunction. In Physiology and Pathology of Chloride Transporters and Channels in the Nervous System-From molecules to diseases. Edited by: Alvarez-Leefmans FJ, Delpire E. New York: Elsevier; 2009:425-437.

3. Chiba T, Marcus DC: Nonselective cation and BK channels in apical membrane of outer sulcus epithelial cells. J Membr Biol 2000, 174:167-179.

4. Lee JH, Marcus DC: Endolymphatic sodium homeostasis by Reissner's membrane. Neuroscience 2003, 119:3-8.

5. Kim SH, Kim KX, Raveendran NN, Wu T, Pondugula SR, Marcus DC: Regulation of ENaC-mediated sodium transport by glucocorticoids in Reissner's membrane epithelium. Am J Physiol, Cell Physiol 2009, 296:C544-C557.

6. Marcus DC, Raveendran NN, WU T: Reissner's membrane, mouse, GEO GSE6196 [http://www.ncbi.nlm.nih.gov/geo/query/acc.cgi?acc=GSE6196].

7. Yagi J, Wenk HN, Naves LA, McCleskey EW: Sustained currents through ASIC3 ion channels at the modest $\mathrm{pH}$ changes that occur during myocardial ischemia. Circ Res 2006, 99:501-509.

8. Ishikawa T, Marunaka Y, Rotin D: Electrophysiological characterization of the rat epithelial $\mathrm{Na}^{+}$channel (rENAC) expressed in MDCK cells. Effects of $\mathrm{Na}^{+}$and $\mathrm{Ca}^{2+}$. J Gen Physiol 1998, 111:825-846.

9. Warncke J, Lindemann B: Voltage dependence of $\mathrm{Na}$ channel blockage by amiloride: relaxation effects in admittance spectra. J Membr Biol 1985, 86:255-265.

10. Palmer LG: Modulation of apical Na permeability of the toad urinary bladder by intracellular $\mathrm{Na}, \mathrm{Ca}$, and $\mathrm{H}$. J Membr Biol 1985, 83:57-69.

11. Bize V, Horisberger JD: Sodium self-inhibition of human epithelial sodium channel: selectivity and affinity of the extracellular sodium sensing site. Am J Physiol Renal Physiol 2007, 293:F1137-F1146.

12. Hille B: Selective Permeability: Independence. Ion Channels of Excitable Membranes. Third edition. Sunderland, MA: Sinauer Associates, Inc; 2001, 441-470.

13. del Monaco S, Assef $Y$, Kotsias BA: Epithelial sodium channel in a human trophoblast cell line (BeWo). J Membr BiOl 2008, 223:127-139.

14. Snyder PM, Olson DR, Bucher DB: A pore segment in DEG/ENaC Na(+) channels. J Biol Chem 1999, 274:28484-28490.

15. Ji HL, Bishop LR, Anderson SJ, Fuller CM, Benos DJ: The role of Pre-H2 domains of alpha- and delta-epithelial $\mathrm{Na}^{+}$channels in ion permeation, conductance, and amiloride sensitivity. J Biol Chem 2004, 279:8428-8440.

16. Lyashchenko AK, Tibbs GR: lon binding in the open HCN pacemaker channel pore: fast mechanisms to shape "slow" channels. J Gen Physiol 2008, 131:227-243

17. Marcus DC, Chiba T: $\mathrm{K}^{+}$and $\mathrm{Na}^{+}$absorption by outer sulcus epithelial cells. Hear Res 1999, 134:48-56.

18. Matalon S, Lazrak A, Jain L, Eaton DC: Invited review: biophysical properties of sodium channels in lung alveolar epithelial cells. J Appl Physiol 2002, 93:1852-1859.

19. Alvarez de la Rosa D, Canessa CM, Fyfe GK, Zhang P: Structure and regulation of amiloride-sensitive sodium channels. Annu Rev Physiol 2000, 62:573-594.

20. Vandorpe DH, Ciampolillo F, Green RB, Stanton BA: Cyclic nucleotide-gated cation channels mediate sodium absorption by IMCD (mIMCD-K2) cells. Am J Physiol, Cell Physiol 1997, 272:C901-C910.

21. Meltzer RH, Kapoor N, Qadri YJ, Anderson SJ, Fuller CM, Benos DJ: Heteromeric assembly of acid-sensitive ion channel and epithelial sodium channel subunits. J Biol Chem 2007, 282:25548-25559.

22. Kim KX, Marcus DC: Inward-rectifier chloride currents in Reissner's membrane epithelial cells. Biochem Biophys Res Commun 2010, 394:434-438.

23. Schoenmakers TJ, Visser GJ, Flik G, Theuvenet AP: CHELATOR: an improved method for computing metal ion concentrations in physiological solutions. BioTechniques 1992, 12:870-879.

doi:10.1186/1472-6793-11-4

Cite this article as: Yamazaki et al: Sodium selectivity of Reissner's membrane epithelial cells. BMC Physiology 2011 11:4. 